\title{
PENERAPAN METODE MENGAJAR YESUS MENURUT INJIL SINOPTIK DALAM PELAKSANAAN PENDIDIKAN AGAMA KRISTEN DI SMA GAMALIEL MAKASSAR
}

\author{
Imanuel Agung \\ imungs81@yahoo.com \\ Made Astika \\ astikadek@yahoo.com
}

\begin{abstract}
ABSTRAK
Adapun yang menjadi tujuan penulisan ini ialah untuk memberikan suatu penjelasan mengenai metode mengajar yang Yesus gunakan dalam pengajaran-Nya yang tertuang dalam Injil Sinoptik. Selain itu penulisan ini bertujuan untuk mengetahui sejauh mana penerapan metode mengajar Yesus dalam pelaksanaan PAK di SMA Gamaliel Makassar.

Metode yang digunakan untuk mengumpulkan data dalam penulisan ini adalah sebagai berikut: Pertama, metode kepustakaan atau literatur, yaitu penggalian data melalui penyelidikan terhadap buku-buku yang ada, baik di perpustakaan Sekolah Tinggi Theologia Jaffray Makassar, maupun kumpulan buku pribadi penulis yang berhubungan dengan pokok masalah yang dibahas. Kedua, penulis juga melakukan penelitian lapangan untuk mendapatkan data-data yang berhubungan dengan penulisan ini. Teknik yang digunakan penulis ialah penyebaran angket kepada siswa-siswi di SMA Gamaliel Makassar dan wawancara terhadap guru PAK yang ada di sekolah tersebut. Angket tersebut disebarkan untuk membuktikan penerapan metode mengajar Yesus dalam proses belajar mengajar di SMA Gamaliel Makassar sebagaimana yang diungkapkan guru melalui wawancara dengan penulis.

Dalam pelayanan-Nya sebagai pengajar, Yesus menggunakan beberapa metode. Metode, metode yang Yesus gunakan antara lain, metode pertanyaan, metode cerita (perumpamaan/ilustrasi), metode ceramah (khotbah), menggunakan benda atau objek sebagai alat peraga dan juga menggunakan metode diskusi. Dapat dikatakan bahwa Yesus adalah guru yang kreatif, karena dalam setiap pengajaran-Nya Yesus menggunakan metode-metode yang bervariasi, bergantung kepada tujuan, bahan, situasi pendengar, serta lingkungan-Nya.
\end{abstract}

Kata kunci: Metode Mengajar, Injil Sinoptik, Pelaksanaan Pendidikan Agama Kristen. 


\section{PENDAHULUAN}

\section{Latar Belakang}

Pelaksanaan Pendidikan Agama Kristen (selanjutnya disebutkan sebagai PAK) di sekolah bukan hanya realisasi dari mandat negara yang tertuang dalam Garis-Garis Besar Haluan Negara (GBHN) dan Undangundang tentang Sistem Pendidikan Nasional (Sisdiknas) saja, namun juga memiliki dasar teologis yang terdapat dalam amanat agung Tuhan Yesus. Pada masa kini tugas mengajar sebagaimana yang terdapat dalam amanat ini salah satunya diwujudkan dalam lembaga pendidikan umum, dalam hal ini sekolah sebagai penyelenggara pendidikan. Penyelenggaraan PAK di sekolah terwujud dalam mata pelajaran Agama Kristen yang dilaksanakan oleh guru mata pelajaran PAK dengan tujuan agar peserta didik dapat mengalami perubahan hidup yang menyeluruh baik dari segi kognitif, afektif dan psikomotoriknya.

Untuk dapat mencapai hasil yang maksimal dalam penyelenggaraan PAK ini beberapa faktor turut mempengaruhi, baik dari pengajar, peserta didik maupun dari lingkungan. Salah satu faktor yang penulis maksudkan adalah faktor metode yang digunakan pengajar ketika yang bersangkutan menyampaikan materi pembelajaran. Metode mengajar menjadi salah satu faktor penting dalam ketercapaian hasil maksimal dalam kegiatan belajar mengajar. Bila dipandang dari segi ilmu komunikasi, metode mengajar merupakan sarana bagi pengajar untuk mengkomunikasikan pengetahuan, ide, atau kebenaran yang ada padanya kepada peserta didiknya. Dalam konteks PAK metode mengajar merupakan sarana yang dapat membawa peserta didik dalam pengenalan kepada Tuhan Yesus dan firman-Nya. ${ }^{1}$

Homrighausen menyatakan bahwa, dalam PAK, metode adalah suatu pekerjaan yang aktif, yang dilakukan bagi Tuhan dan sesama manusia supaya kedua pihak dapat bertemu satu sama lain. ${ }^{2}$ Namun demikian dalam pelaksanaan PAK di sekolah masih kita jumpai pengajar-pengajar yang belum maksimal dalam menggunakan metode ketika mereka mengajar, sehingga peserta didik tidak mengalami perjumpaan dengan Tuhan dan firman-Nya dan mengalami perubahan hidup, yang sebenarnya adalah tujuan dari PAK. Seyogyanya para pengajar Kristen, khususnya yang terlibat dalam pelaksanaan PAK di sekolah memperhatikan persoalan mengenai metode mengajar ini, supaya peserta didik benar-benar mengalami perjumpaan dengan Tuhan Yesus dan firman-Nya, sehingga mereka dapat mengenal Tuhan Yesus secara pribadi. Sebagai konsekuensinya mereka akan mengalami perubahan hidup, baik dalam

\footnotetext{
${ }^{1}$ Paulus Lilik Kristianto, Prinsip dan Praktek Pendidikan Agama Kristen (Yogyakarta: Penerbit ANDI, 2006), 83.

${ }^{2}$ Homrighausen dan I.H. Enklaar, Pendidikan Agama Kristen (Jakarta: BPK Gunung Mulia, 2004), 74.
} 
pengetahuan, sikap, nilai-nilai yang dianut maupun tingkah lakunya menjadi sesuai dengan firman Tuhan. Dalam kitab-kitab Injil, dapat dilihat bahwa Yesus menggunakan metode dalam menyampaikan pengajaran-Nya. Daniel Nuhamara menyatakan bahwa, "Tuhan Yesus sendiri walaupun dalam kewibawaan-Nya yang tinggi sebagai Anak Allah, juga telah menggunakan metode yang bermacam-macam dan efektif dalam menjalankan tugas-Nya untuk mengajar." ${ }^{3}$

Sekalipun metode-metode yang digunakan oleh Yesus telah digunakan kurang lebih dua ribu tahun yang telah lalu, namun demikian metode-metode tersebut masih sangat relevan bila digunakan pada masa kini, khususnya dalam pelaksanaan PAK di sekolah.

\section{Pokok Masalah}

Adapun yang menjadi masalah pokok dalam penulisan ini yaitu:

Pertama, metode apa sajakah yang Yesus gunakan dalam setiap pengajaran-Nya menurut Injil Sinoptik.

Kedua, sejauh mana metode tersebut diterapkan atau digunakan dalam pelaksanaan PAK khususnya di SMA Gamaliel Makassar.

\section{Tujuan Penulisan}

Adapun yang menjadi tujuan penulisan ini ialah untuk memberikan suatu penjelasan mengenai metode mengajar yang Yesus gunakan dalam pengajaran-Nya yang tertuang dalam Injil Sinoptik. Selain itu penulisan ini bertujuan untuk mengetahui sejauh mana penerapan metode mengajar Yesus dalam pelaksanaan PAK di SMA Gamaliel Makassar.

\section{Manfaat Penulisan}

Pertama, diharapkan guru-guru PAK dapat melihat dari kehidupan dan pelayanan Yesus serta meneladani-Nya, khususnya yang berkaitan dengan bagaimana Yesus menggunakan berbagai macam metode dalam menyampaikan pengajaran-Nya.

Kedua, guru-guru PAK dapat mencapai tujuan sebagaimana yang diharapkan, bukan saja sesuai tuntutan kurikulum, namun terlebih sesuai dengan yang Tuhan ingin capai dalam kehidupan tiap-tiap peserta didik.

Ketiga, penulisan ini diharapkan dapat menjadi bahan pengaya bagi mahasiswa Teologi, khususnya yang mengambil program studi Pendidikan Agama Kristen dalam memahami metode mengajar Yesus dan peran pentingnya bagi pencapaian tujuan PAK di sekolah.

Keempat, agar dapat memenuhi persyaratan akademik dalam rangka penyelesaian program Stratum Satu (Sl) di Sekolah Tinggi Theologia Jaffray Makassar.

\footnotetext{
${ }^{3}$ Daniel Nuhamara, Pembimbing PAK (Bandung: Jurnal Info Media, 2007), 137.
} 


\section{Metode Penelitian}

Metode yang digunakan untuk mengumpulkan data dalam penulisan ini adalah sebagai berikut:

Pertama, metode kepustakaan atau literatur, yaitu penggalian data melalui penyelidikan terhadap buku-buku yang ada, baik di perpustakaan Sekolah Tinggi Theologia Jaffray Makassar, maupun kumpulan buku pribadi penulis yang berhubungan dengan pokok masalah yang dibahas.

Kedua, penulis juga melakukan penelitian lapangan untuk mendapatkan data-data yang berhubungan dengan penulisan ini. Teknik yang digunakan penulis ialah penyebaran angket kepada siswa-siswi di SMA Gamaliel Makassar dan wawancara terhadap guru PAK yang ada di sekolah tersebut. Angket tersebut disebarkan untuk membuktikan penerapan metode mengajar Yesus dalam proses belajar mengajar di SMA Gamaliel Makassar sebagaimana yang diungkapkan guru melalui wawancara dengan penulis.

\section{Pembatasan Penulisan}

Dalam penulisan ini, penulis menitikberatkan pada pembahasan tentang metode dalam mengajar, khususnya dalam pelaksanaan PAK. Lebih khusus lagi penulis menyoroti bagaimana metode yang digunakan Yesus dalam pengajaran-Nya selama kehidupan dan pelayanan-Nya di muka bumi ini serta penerapannya pada pelaksanaan PAK di sekolah, dalam hal ini SMA Gamaliel Makassar menjadi objek penelitian penulis.

Untuk melihat tentang metode mengajar Yesus, penulis hanya melihat metode mengajar Yesus yang tercatat dalam Kitab Injil Sinoptik, yaitu Injil yang ditulis oleh Matius, Markus dan Lukas. Karena dari dalamnya kita dapat belajar banyak tentang metode apa saja yang Yesus lakukan dan dalam situasi bagaimana metode tersebut diterapkan.

\section{METODOLOGI PENELITIAN}

\section{Gambaran Umum Lokasi Survei}

Dalam penulisan ini penulis melaksanakan penelitian lapangan yang berlokasi di SMA Gamaliel Makassar. Adapan gambaran secara umum lokasi survei yang penulis lakukan adalah sebagai berikut:

\section{Sejarah Singkat Berdirinya SMA Gamaliel Makassar}

SMA Gamaliel Makassar adalah salah satu sekolah di bawah naungan Komisi Pendidikan Gereja Kristen Indonesia (GKI) Sulawesi Selatan Jemaat Makassar. Sekolah ini didirikan pertama kali pada tahun 1980 dengan jumlah murid pertama sebanyak 27 orang dan diasuh oleh 14 orang guru. Pada tahun 1995 SMA Gamaliel berstatus "Diakui." Dan dari tahun 1995 sampai sekarang berstatus "Disamakan." Bahkan SMA ini sudah dua kali 
terakreditasi dengan nilai A+. Hasil ini menunjukkan kualitas SMA ini semakin hari semakin meningkat. ${ }^{4}$

Saat ini SMA Gamaliel Makassar memiliki jumlah murid sebanyak 364 orang dan diasuh oleh 24 orang guru. ${ }^{5}$

\section{Letak Geografis}

SMA Gamaliel Makassar terletak di tengah-tengah kota Makassar, tepatnya di jalan Ince Nurdin No. 5A, di belakang kawasan Monumen Mandala Makassar. Lokasi sekolah ini sangat strategis dan mudah dijangkau, baik dengan kendaraan umum maupun kendaraan pribadi.

\section{Visi dan Misi SMA Gamaliel Makassar ${ }^{6}$}

SMA Gamaliel Makassar sebagai bagian dari Sekolah Gamaliel Makassar memiliki visi membangun generasi baru yang kokoh dalam iman, hikmat dalam berkehendak, bijak dalam bertindak dan gigih dalam berkarya. Melalui visi ini Sekolah Gamaliel Makassar terpanggil untuk turut membangun generasi baru di atas dasar iman yang kokoh, membangun generasi baru yang penuh hikmat dalam berkehendak, membangun generasi baru yang bijak dalam bertindak serta menumbuh kembangkan budaya semangat juang yang gigih dalam beradaptasi dengan komunitas untuk menginspirasi ide kreasi sehingga menghasilkan buah karya yang inovatif dan bermanfaat bagi kesejahteraan diri sendiri dan sesama. Semangat juang dalam berkarya, tidak cukup hanya dibentuk secara akademik saja, melainkan harus juga dibangun di atas dasar iman yang kokoh, sehingga terbentuk tegaknya karakter yang penuh hikmat, yang menginspirasikan kualitas dan kuantitas tindakan yang bijak dalam belajar dan berusaha.

Selanjutnya misi dari SMA Gamaliel Makassar sebagai bagian dari Sekolah Gamaliel Makassar adalah:

Pertama, mengembangkan aktivitas siswa untuk membangun konsep wawasan dan pengetahuan (knowledge), kecakapan hidup (life skill) dan semangat kewirausahaan (enterpreneur spirit), serta sikap yang merefleksikan nilai-nilai kristiani dalam kegiatan belajar dan berperilaku.

Kedua, mengembangkan Kurikulum Tingkat Satuan Pendidikan (KTSP) yang adaptif terhadap perkembangan ilmu pedagogis, IPTEK, dan budaya, dengan mengintegrasikan nilai-nilai kristiani yang Alkitabiah.

\footnotetext{
${ }^{4}$ Matheus Limbongan, Wawancara Oleh Penulis, Makassar, 31 Maret 2011.

${ }^{5}$ Paul Djadi, Wawancara Oleh Penulis, Makassar, 31 Maret 2011.

6 "Profil Sekolah Gamaliel."Gamalielschool.org; diakses tanggal 15 April 201; tersedia di http://gamalielschool.org/index.php?option=com_content\&view=article\& $\&$ id=7:profile sekolah-gamaliel\&catid=1:profile-sekolah\&Itemid=9.
} 
Ketiga, mengembangkan sistem manajemen sekolah yang inovatif berdasarkan standar profesi yang didukung oleh komunitas GKI Sulsel Jemaat Makassar.

Keempat, mengembangkan kualitas sumber daya tenaga kependidikan dan manajemen sekolah berdasarkan nilai-nilai kristiani dengan disertai penghargaan berdasarkan kinerja.

\section{Jenis Penelitian}

Jenis penelitian yang penulis gunakan ialah penelitian kuantitatif yang bersifat survei deskriptif. Winarno Surachmad menjelaskan bahwa survei pada umumnya merupakan pengumpulan data dari sejumlah unit atau individu dalam waktu atau jangka waktu yang bersamaan. ${ }^{7}$

Dalam melaksanakan penelitian ini, penulis mengumpulkan data salah satunya melalui angket. Dengan data yang telah didapat penulis mengklasifikasikan data tersebut dalam bentuk tabel dan menginterpretasikan serta mendekarya ilmiahkannya. Sedangkan data yang didapat dari hasil wawancara penulis dekarya ilmiahkan secara kualitatif.

\section{Populasi dan Sampel Populasi}

Menurut Sumanto, yang disebut sebagai populasi adalah kelompok di mana seseorang peneliti akan memperoleh hasil penelitian yang dapat disamaratakan. ${ }^{8} \quad$ Dalam hal ini populasi yang penulis teliti ialah siswa kelas X dan XI dari SMA Gamaliel Makassar yang berjumlah 240 orang, dan 2 orang guru agama Kristen. Alasan pemilihan populasi ini karena kelaskelas inilah yang masih aktif melaksanakan kegiatan belajar mengajar saat penulis melakukan penelitian, dan 2 orang guru inilah yang mengajar mata pelajaran agama Kristen di sekolah ini.

Sampel

Sampel adalah "Suatu prosedur dalam mana hanya sebagian dari populasi saja yang diambil dan dipergunakan untuk menentukan sifat serta ciri yang dikehendaki dari populasi."

Dalam hal ini penulis mengambil sampel sebanyak 100 orang siswa dan 1 orang guru Agama Kristen dari populasi yang diteliti.

7 Winarno Surachmad, Dasar dan Tehnik Research Pengantar Metodologi Ilmiah (Bandung: Tarsito, 1978), 134.

${ }^{8}$ Sumanto, Metodologi Penelitian Sosial dan Pendidikan (Yogyakarta: Penerbit Andi Offset, 1990), 23.

${ }^{9}$ Moh. Nazir, Metode Penelitian (Jakarta: Ghalia Indonesia, 1988), 325. 


\section{Teknik Pengumpulan Data}

Dalam penulisan ini, penulis menggunakan beberapa teknik pengumpulan data guna memperoleh data yang valid berkaitan dengan pokok masalah yang dibahas, yaitu literatur, angket dan wawancara.

\section{Literatur}

Melalui teknik ini, penulis memperoleh informasi berkaitan dengan pokok masalah yang dibahas dari buku-buku yang ada di perpustakaan Sekolah Tinggi Theologia Jaffray Makassar, maupun dari buku-buku koleksi pribadi.

\section{Angket}

Untuk dapat memperoleh data yang diperlukan dalam penelitian ini, penulis menggunakan angket yang harus responden isi. Adapun bentuk pertanyaan yang digunakan dalam penelitian ini ialah pertanyaan tertutup (multiple choice). Menurut Sutrisno Hadi pertanyaan tertutup (multiple choice) merupakan, "Pertanyaan yang variasi jawabannya adalah ditentukan dan disusun terlebih dahulu sehingga responden tidak mempunyai kebebasan untuk memberikan jawaban kecuali pada jawaban yang sudah ditentukan." 10

\section{Wawancara}

Wawancara merupakan salah satu cara untuk mendapatkan informasi. Menurut Husaini Usman, "Wawancara ialah tanya jawab lisan antara dua orang atau lebih secara langsung." Beberapa bagian dalam penulisan ini ditulis berdasarkan hasil wawancara penulis dengan nara sumber yang terkait.

\section{Teknik Analisis Data}

Data yang telah terkumpul dalam penelitian angket akan dianalisis menggunakan teknik persentase dan hasilnya akan disajikan dalam bentuk tabel serta diinterpretasikan. Sedangkan data yang terkumpul dalam penelitian wawancara akan dianalisis dengan cara deskriptif.

Dalam menganalisis hasil angket, penulis menggunakan teknik persentase dengan rumus sebagai berikut:

$$
\begin{array}{ll}
\mathrm{n}=-\mathrm{x} \times 100 \% & \text { Keterangan }^{12}: \\
\mathrm{N} & \%=\text { Persentase } \\
& \mathrm{n}=\text { Jumlah jawaban responden } \\
& \mathrm{N}=\text { Jumlah responden }
\end{array}
$$

\footnotetext{
${ }^{10}$ Sutrisno Hadi, Metodologi Research Jilid 2 (Yogyakarta: Penerbit Andi Offset, 1990), 158.

${ }^{11}$ Husaini Usman dan Purnomo Setiady Akbar, Metodologi Penelitian Sosial (Jakarta: Bumi Aksara, 1996), 59.

${ }^{12}$ Mohamad Ali, Penelitian Kependidikan (Bandung: Angkasa, 1981), 184.
} 


\section{PEMBAHASAN HASIL PENELITIAN}

\section{Interpretasi dan Dekarya ilmiah}

Untuk mengetahui metode-metode mengajar apa saja yang diterapkan di SMA Gamaliel Makassar, khususnya berhubungan dengan metode mengajar yang Yesus lakukan menurut Injil Sinoptik, penulis memberikan beberapa pertanyaan dalam bentuk angket kepada sampel, yaitu sejumlah siswa SMA Gamaliel Makassar serta mewawancarai seorang guru mata pelajaran Agama Kristen dan kemudian menginterpretasikan hasil angket dan wawancara tersebut serta mendekarya ilmiahkannya.

\section{Metode Mengajar Yesus Menurut Injil Sinoptik}

Berdasarkan penelitian yang dilakukan penulis menggunakan angket, didapat data dari responden sebagai berikut:

Tabel l. Menggunakan Metode Pertanyaan-Pertanyaan

\begin{tabular}{|c|c|c|}
\hline $\begin{array}{l}\text { 1. Apakah guru anda menggunakan pertanyaan- } \\
\text { pertanyaan untuk memotivasi anda? }\end{array}$ & $\mathbf{n}$ & $\%$ \\
\hline Ya & 55 & 55 \\
\hline Tidak & - & - \\
\hline Kadang-kadang & 45 & 45 \\
\hline $\mathrm{N}$ & 100 & 100 \\
\hline $\begin{array}{l}\text { 2. Apakah guru anda menggunakan pertanyaan- } \\
\text { pertanyaan evaluatif untuk membuat anda memikirkan } \\
\text { kembali pemahaman anda sehingga anda memperoleh } \\
\text { pemahaman yang lebih baik? }\end{array}$ & $\mathbf{n}$ & $\%$ \\
\hline $\mathrm{Ya}$ & 66 & 66 \\
\hline Tidak & - & - \\
\hline Kadang-kadang & 34 & 34 \\
\hline $\mathrm{N}$ & 100 & 100 \\
\hline $\begin{array}{l}\text { 3. Apakah guru anda menggunakan pertanyaan- } \\
\text { pertanyaan analitis untuk memancing anda berpikir } \\
\text { lebih dalam mengenai materi pelajaran? }\end{array}$ & $\mathbf{n}$ & $\%$ \\
\hline Ya & 71 & 71 \\
\hline Tidak & - & - \\
\hline Kadang-kadang & 29 & 29 \\
\hline $\mathrm{N}$ & 100 & 100 \\
\hline
\end{tabular}

Seperti tertera dalam tabel l, didapatkan jawaban bagi pertanyaan yang berkaitan dengan metode pertanyaan yang bertujuan untuk memotivasi siswa (pertanyaan nomor 1) sebagai berikut, dari 100 orang responden, 55 orang di antaranya atau sebesar 55\% menjawab "ya" dan 45 orang sisanya atau sebesar 45\% menjawab "kadang-kadang." Hal ini 
menunjukkan bahwa metode pertanyaan yang bertujuan untuk memotivasi murid digunakan dalam kegiatan belajar - mengajar, khususnya dalam mata pelajaran Agama Kristen di SMA Gamaliel Makassar. Namun demikian dapat diketahui bahwa bentuk pertanyaan ini tidak selalu digunakan, karena sebanyak 45\% responden siswa menjawab opsi "kadang-kadang." Diharapkan guru mata pelajaran dapat menggunakan pertanyaan untuk memotivasi murid pada saat yang tepat, sehingga murid termotivasi dalam menerapkan apa saja yang telah dipelajari bersama dalam kelas.

Selanjutnya berkaitan dengan metode pertanyaan evaluatif, yaitu metode pertanyaan yang digunakan guru untuk membuat siswa memikirkan kembali pemahaman mereka sehingga mereka memperoleh pemahaman yang lebih baik (pertanyaan nomor 2), didapatkan data sebagai berikut, dari 100 orang responden, 66 orang di antaranya atau sebesar 66\% menjawab "ya" dan 34 orang sisanya atau sebesar 34\% menjawab "kadangkadang." Dalam hal ini dapat diketahui bahwa bentuk pertanyaan evaluatif digunakan oleh guru dalam mengajar, khususnya ketika guru mata pelajaran ingin membuat siswa memiliki pemahaman yang lebih baik. Dengan bentuk pertanyaan evaluatif ini siswa dibawa kepada suatu penilaian terhadap dirinya dan pemahamannya. Dalam kaitan dengan hal ini Bapak Paul Djadi yang mendampingi penulis selama penelitian dilakukan menjelaskan bahwa, "Siswa sekarang tidak boleh serta merta disalahkan apabila mereka memiliki pemahaman yang keliru, guru harus pandai-pandai mengarahkan mereka, salah satunya dengan bentuk pertanyaan evaluatif bagi diri mereka."13 Diharapkan guru dapat menggunakan bentuk pertanyaan evaluatif untuk membuat siswa dapat memperbaiki pemahamannya yang keliru.

Dalam menyampaikan pelajaran guru menggunakan bentuk pertanyaan analitis guna memancing siswa berpikir secara mendalam berkaitan dengan materi pelajaran yang diajarkan (pertanyaan nomor 3). Dari hasil penelitian didapat data sebagai berikut, dari 100 orang responden, 71 orang di antaranya atau sebesar $71 \%$ menjawab "ya" dan 29 orang sisanya atau sebesar 29\% menjawab "kadang-kadang." Persentase jawaban "ya" dan "kadang-kadang" dalam hasil penelitian pada tabel di atas menunjukkan bahwa metode pertanyaan-pertanyaan digunakan oleh guru dalam menyampaikan pelajaran, khususnya mata pelajaran Agama Kristen. Guru mata pelajaran diharapkan dapat juga menggunakan pertanyaan analitis guna memancing siswa berpikir lebih dalam mengenai apa yang mereka pelajari.

Dalam wawancara penulis dengan Bapak Paul Djadi selaku guru bidang studi Agama Kristen, didapat informasi bahwa penggunaan metode pertanyaan tidak selalu dalam bentuk yang sama, tergantung situasi yang ada. Misalnya, bentuk pertanyaan motivasi digunakan untuk mendorong

\footnotetext{
${ }^{13}$ Paul Djadi, Wawancara Oleh Penulis, Makassar, 31 Maret 2011.
} 
murid mencontoh teladan-teladan yang dikemukakan dalam materi pelajaran. Bentuk pertanyaan evaluatif dan analitis biasanya digunakan pada akhir pelajaran. ${ }^{14}$

Kesimpulan yang didapat dari data tersebut di atas yaitu, metode pertanyaan-pertanyaan digunakan dalam kegiatan belajar mengajar di kelas dalam pelaksanaan PAK di SMA Gamaliel Makassar, namun tidak selalu digunakan. Adapun penggunaannya tergantung situasi yang ada.

Tabel 2.

Menggunakan Metode Cerita (Perumpamaan/Ilustrasi)

\begin{tabular}{|c|c|c|}
\hline $\begin{array}{l}\text { 4. Apakah guru anda menggunakan cerita-cerita (ilustrasi) } \\
\text { dalam mengajar? }\end{array}$ & $\mathrm{n}$ & $\%$ \\
\hline $\mathrm{Ya}$ & 72 & 72 \\
\hline Tidak & 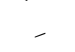 & 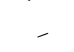 \\
\hline Kadang-kadang & 28 & 28 \\
\hline $\mathrm{N}$ & 100 & 100 \\
\hline $\begin{array}{l}\text { 5. Apakah cerita-cerita (ilustrasi) yang disampaikan guru } \\
\text { anda sesuai dengan materi pelajaran? }\end{array}$ & $\mathrm{n}$ & $\%$ \\
\hline $\mathrm{Ya}$ & 83 & 83 \\
\hline Tidak & - & - \\
\hline Kadang-kadang & 17 & 17 \\
\hline $\mathrm{N}$ & 100 & 100 \\
\hline $\begin{array}{l}\text { 6. Sebelum membahas materi pelajaran, apakah guru anda } \\
\text { menggunakan cerita-cerita (ilustrasi) sebagai } \\
\text { pendahuluan? }\end{array}$ & $\mathrm{n}$ & $\%$ \\
\hline $\mathrm{Ya}$ & 37 & 37 \\
\hline Tidak & - & - \\
\hline Kadang-kadang & 63 & 63 \\
\hline $\mathrm{N}$ & 113 & 100 \\
\hline
\end{tabular}

Dari hasil penelitian berkaitan dengan metode cerita (ilustrasi), didapatkan data sebagai berikut:

Pertama, dalam hal penggunaan (pertanyaan nomor 4), didapatkan data sebagai berikut, sebanyak 72 responden atau sebesar $72 \%$ menjawab "ya" dan sisanya sebanyak 28 responden atau sebesar 28\% menjawab "kadang-kadang." Hal ini menunjukkan bahwa dalam mengajar guru memberikan penjelasan-penjelasan menggunakan cerita (ilustrasi). Diharapkan penggunaan cerita (ilustrasi) dalam mengajar dapat disesuaikan dengan kebutuhan mengingat cerita (ilustrasi) dapat menolong siswa memahami bahan pelajaran dengan lebih baik.

Kedua, dalam hal kesesuaian isi cerita dengan bahan pelajaran (pertanyaan nomor 5), didapatkan data sebagai berikut, sebanyak 83

${ }^{14}$ Paul Djadi, Wawancara Oleh Penulis, Makassar, 31 Maret 2011. 
responden atau sebesar 83\% menjawab "ya" sedangkan 17 orang lainnya atau sebesar $17 \%$ menjawab "kadang-kadang." Dari sini dapat dilihat bahwa isi cerita yang disampaikan guru dapat dikatakan ada hubungannya dengan pelajaran yang diajarkan, sekalipun kadang-kadang guru menggunakan cerita di luar bahan pelajaran. Berdasarkan wawancara yang dilakukan penulis, terkadang guru teringat akan sebuah cerita yang inspiratif dan menyampaikannya kepada siswa sekalipun cerita tersebut tidak sesuai dengan bahan yang sedang dipelajari. ${ }^{15}$

Ketiga, dalam hal fungsi cerita dalam mengajar, dengan pertanyaan "Sebelum membahas materi pelajaran, apakah guru anda menggunakan cerita-cerita (ilustrasi) sebagai pendahuluan?" (pertanyaan nomor 6) didapatkan data sebagai berikut, sebanyak 37 responden atau sebesar 37\% menjawab "ya" sedangkan 63 orang lainnya atau sebesar 63\% menjawab "kadang-kadang." Hal ini menunjukkan bahwa kadang-kadang guru menggunakan cerita (ilustrasi) sebagai pendahuluan dalam mengajar. Diharapkan guru dapat menggunakan cerita (ilustrasi) sebagai pendahuluan dalam mengajar, mengingat cerita yang menarik akan memikat siswa terhadap apa yang akan dipelajari saat itu.

Tabel 3.

Menggunakan Metode Ceramah atau Khotbah

\begin{tabular}{|c|c|c|}
\hline $\begin{array}{l}\text { 7. Dalam mengajar apakah guru anda menggunakan } \\
\text { metode ceramah (menerangkan pelajaran)? }\end{array}$ & $\mathrm{n}$ & $\%$ \\
\hline $\mathrm{Ya}$ & 56 & 56 \\
\hline Tidak & 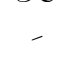 & 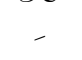 \\
\hline Kadang-kadang & 44 & 44 \\
\hline $\mathrm{N}$ & 100 & 100 \\
\hline
\end{tabular}

Dari pertanyaan nomor 7 pada tabel di atas dapat dikatakan bahwa guru menggunakan metode ceramah, yaitu metode penyampaian informasi satu arah saat menyampaikan bahan pelajaran sekalipun tidak selalu demikian. Berkaitan dengan hal ini dapat dilihat dari jawaban responden siswa, dapat diketahui bahwa sebanyak 56 orang responden atau sebesar 56\% menjawab "ya" dan sebanyak 44 orang lainnya atau sebesar 44\% responden siswa menjawab "kadang-kadang." Data ini menjelaskan bahwa metode ceramah digunakan sekalipun intensitasnya tidak selalu dilakukan. Dari hasil wawancara dengan penulis, Bapak Paul Djadi menyatakan bahwa metode ceramah tidak dilakukan sepanjang mata pelajaran berlangsung, namun ada kalanya diintegraskan dengan metode-metode yang lainnya supaya tidak membosankan. Beberapa metode yang dapat diintegrasikan bersama metode ini ialah, cerita, diskusi, maupun penggunaan fasilitas

\footnotetext{
${ }^{15}$ Paul Djadi, Wawancara Oleh Penulis, Makassar, 31 Maret 2011.
} 
proyektor LCD. ${ }^{16}$ Diharapkan penggunaan metode ceramah dapat dilakukan dengan kreatif sehingga metode ini efektif dikerjakan dan mencapai hasil yang maksimal.

Tabel 4.

Menggunakan Benda atau Objek

\begin{tabular}{|c|c|c|}
\hline $\begin{array}{l}\text { 8. Dalam mengajar apakah guru anda menggunakan alat } \\
\text { peraga? }\end{array}$ & $\mathrm{n}$ & $\%$ \\
\hline $\mathrm{Ya}$ & 6 & 6 \\
\hline Tidak & - & - \\
\hline Kadang-kadang & 94 & 94 \\
\hline $\mathrm{N}$ & 100 & 100 \\
\hline
\end{tabular}

Benda atau objek dapat dijadikan alat dalam menyampaikan pelajaran. Namun dari hasil penelitian di lapangan, penulis mendapati bahwa guru kadang-kadang menggunakan alat peraga saat mengajar. Hasil angket pada tabel 4 pertanyaan nomor 8 menunjukkan hal ini, yaitu sebanyak 94 orang responden atau sebesar 94\% menjawab "kadangkadang" sedangkan sisanya sebanyak 6 orang responden atau sebesar $6 \%$ menjawab "ya." Bapak Paul Djadi menyatakan bahwa alat peraga yang kadang kala dia gunakan adalah proyektor LCD. ${ }^{17}$ Diharapkan guru lebih meningkatkan penggunaan alat peraga dalam mengajar, karena dengan alat peraga siswa mendapatkan penjelasan dan visualisasi dari bahan pelajaran yang ada sehingga mereka akan lebih mudah memahami materi pembelajaran.

Tabel 5 .

Menggunakan Metode Diskusi

\begin{tabular}{|c|c|c|}
\hline $\begin{array}{l}\text { 9. Apakah guru anda menggunakan metode diskusi ketika } \\
\text { mengajar? }\end{array}$ & $\mathrm{n}$ & $\%$ \\
\hline $\mathrm{Ya}$ & 45 & 45 \\
\hline Tidak & - & - \\
\hline Kadang-kadang & 55 & 55 \\
\hline $\mathrm{N}$ & 100 & 100 \\
\hline
\end{tabular}

Metode diskusi merupakan metode yang digunakan secara interaktif. Dari penelitian yang dilakukan didapatkan data sebagai berikut, dari tabel 5 pada pertanyaan nomor 9, didapatkan data sebanyak 45 orang responden siswa atau sebesar 45\% saja yang menjawab "ya" sedangkan sebagian besar yaitu sebanyak 55 orang atau sebesar 55\% menjawab "kadang-kadang." Berdasarkan data ini dapat disimpulkan bahwa guru kadang-kadang

\footnotetext{
${ }^{16}$ Paul Djadi, Wawancara Oleh Penulis, Makassar, 31 Maret 2011.

${ }^{17}$ Idem.
} 
menggunakan metode diskusi saat mengajar dalam kelas. Berkaitan dengan hal ini Bapak Paul Djadi, sebagai pengajar pelajaran Agama Kristen pada kelas X dan XI menyatakan bahwa, "Saat ini dalam mengajar guru harus dapat melibatkan siswa dalam proses belajar - mengajar di kelas. Salah satunya menggunakan metode diskusi. Di sini guru menjadi moderator bagi mereka, sehingga mereka dapat mengembangkan pemahaman mereka tentang materi yang mereka sedang pelajari." 18 Diharapkan guru dapat menerapkan metode diskusi di kelas sesuai dengan kebutuhan dan situasi yang ada, sehingga siswa juga dilibatkan secara aktif dalam kegiatan belajar mengajar.

Pelaksanaan Pendidikan Agama Kristen di SMA Gamaliel Makassar Tabel 6.

Tujuan PAK di Sekolah

\begin{tabular}{|c|c|c|}
\hline $\begin{array}{l}\text { 10. Apakah anda didorong untuk bertumbuh dalam iman } \\
\text { kepada Allah? }\end{array}$ & $\mathbf{n}$ & $\%$ \\
\hline $\mathrm{Ya}$ & 97 & 97 \\
\hline Tidak & - & - \\
\hline Kadang-kadang & 3 & 3 \\
\hline $\mathrm{N}$ & 100 & 100 \\
\hline $\begin{array}{l}\text { 1l. Apakah guru anda menolong anda memiliki } \\
\text { pengetahuan keagamaan yang semakin bertambah, } \\
\text { menjadi pribadi yang terampil dalam hal-hal rohani, } \\
\text { serta memiliki budi pekerti yang baik? }\end{array}$ & $\mathrm{n}$ & $\%$ \\
\hline $\mathrm{Ya}$ & 96 & 96 \\
\hline Tidak & - & - \\
\hline Kadang-kadang & 4 & 4 \\
\hline $\begin{array}{lll}0 & 0\end{array}$ & 100 & 100 \\
\hline $\begin{array}{l}\text { 12. Melalui materi pelajaran yang anda terima, apakah anda } \\
\text { disadarkan tentang peran anda dalam masyarakat, } \\
\text { sehingga selepas dari sekolah anda mampu } \\
\text { berpartisipasi dalam pembangunan masyarakat dan } \\
\text { bangsa? }\end{array}$ & $\mathrm{n}$ & $\%$ \\
\hline $\mathrm{Ya}$ & 76 & 76 \\
\hline Tidak & - & - \\
\hline Kadang-kadang & 24 & 24 \\
\hline 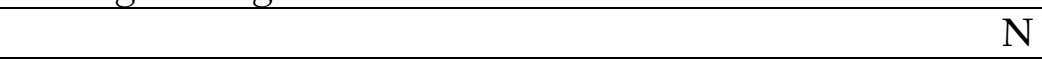 & 100 & 100 \\
\hline
\end{tabular}

Dalam melihat pelaksanaan Pendidikan Agama Kristen (PAK) di SMA Gamaliel Makassar, penulis menitikberatkan pada tujuan dari pelaksanaan PAK di sekolah. Berdasarkan hasil angket, didapatkan data

${ }^{18}$ Paul Djadi, Wawancara Oleh Penulis, Makassar, 31 Maret 2011. 
sebagai berikut, Pertama, berkaitan dengan pertumbuhan iman siswa sebagai peserta didik, penulis mempertanyakan apakah mereka didorong untuk bertumbuh dalam iman kepada Allah (pertanyaan nomor 10). Dari tabel 6 dapat diketahui bahwa sebanyak 97 orang responden siswa atau sebesar 97\% menjawab "ya" sedang sisanya sebanyak 3 orang responden siswa atau hanya sebesar 3\% yang menjawab "kadang-kadang." Hal ini menunjukkan bahwa dalam pelaksanaan PAK di SMA Gamaliel, pertumbuhan iman adalah suatu hal yang penting, sehingga guru mendorong siswa untuk bertumbuh di dalam iman kepada Allah. Diharapkan guru terus memperhatikan hal ini, karena pertumbuhan iman adalah hal yang penting untuk diusahakan selain dari penambahan pengetahuan. Pengetahuan yang bertambah tanpa pertumbuhan iman adalah hal yang sia-sia, karena sebagai orang percaya keduanya harus berjalan seiring dan seimbang. Kedua, berkaitan dengan pertambahan pengetahuan keagamaan, terampil dalam hal-hal rohani, serta memiliki budi pekerti yang baik (pertanyaan nomor ll) dalam tabel 6 dapat diketahui bahwa sebanyak 96 orang responden siswa atau sebesar 96\% menjawab "ya" sedang sisanya sebanyak 4 orang responden siswa atau hanya sebesar 4\% yang menjawab "kadang-kadang." Hal ini menunjukkan bahwa pelaksanaan PAK di SMA Gamaliel Makassar membawa siswa kepada pengetahuan yang semakin meningkat dalam hal-hal keagamaan, dan mereka semakin terampil dalam hal-hal rohani, dan juga memiliki budi pekerti yang baik. Dari pengakuan guru mata pelajaran Agama Kristen di sekolah ini penulis mendapat informasi bahwa siswa di SMA Gamaliel memiliki nilai-nilai yang baik dalam mata pelajaran Agama Kristen. Selain itu mereka mampu memimpin ibadah singkat di kelas setiap pagi sebelum pelajaran dimulai. Dan juga tidak ada laporan kenakalan siswa sekolah ini yang mencolok di luar sekolah, kalaupun ada angkanya sangat kecil. ${ }^{19}$ Diharapkan guru bukan saja menitikberatkan pada peningkatan pengetahuan siswa saja namun dapat membawa siswa meningkat dalam hal keterampilan pada hal-hal rohani dan budi pekerti yang terus meningkat.

Ketiga, dalam hal peran serta siswa dalam masyarakat selepas dari sekolah, penulis menanyakan kepada responden, "Melalui materi pelajaran yang anda terima, apakah anda disadarkan tentang peran anda dalam masyarakat, sehingga selepas dari sekolah anda mampu berpartisipasi dalam pembangunan masyarakat dan bangsa?"(pertanyaan nomor 12). Jawaban yang penulis dapatkan dari hasil angket ialah, dari tabel 6 dapat diketahui bahwa sebanyak 76 orang responden siswa atau sebesar $76 \%$ menjawab "ya" sedang sisanya sebanyak 24 orang responden siswa atau hanya sebesar 24\% yang menjawab "kadang-kadang." Dari hasil ini dapat disimpulkan bahwa pelaksanaan PAK di SMA Gamaliel juga memberikan sebuah kesadaran akan peran siswa dalam masyarakat untuk berpartisipasi

\footnotetext{
${ }^{19}$ Paul Djadi, Wawancara Oleh Penulis, Makassar, 31 Maret 2011.
} 
dalam membangun masyarakat dan bangsa. Namun demikian dari data angket siswa menunjukkan bahwa $24 \%$ responden merasa guru kadangkadang menyadarkan mereka dalam hal ini. Berkaitan dengan hal ini guru hendaknya memperhatikan kembali tujuan dari pelaksanaan PAK di sekolah yang mengacu pada tujuan pendidikan nasional dalam UndangUndang Sistem Pendidikan Nasional dan Garis-Garis Besar Haluan Negara, karena di dalamnya nyata bahwa siswa juga harus menyadari pentingnya keterlibatan dalam pembangunan bangsa dan negara.

Tujuan dalam pelaksanaan PAK khususnya yang berkaitan dengan pertumbuhan iman, yaitu membawa peserta didik mengalami perjumpaan dengan Tuhan harus menjadi prioritas utama dalam kegiatan pembelajaran. Berdasarkan wawancara dengan penulis, Bapak Paul Djadi menjelaskan bahwa sebagai guru PAK ada sebuah beban dalam kehidupannya untuk membawa siswa mengalami perjumpaan dengan Tuhan. ${ }^{20}$ Hal ini mengacu kepada filosofi sekolah Gamaliel, yang dikutip dari Roma 1l:36, "Sebab segala sesuatu adalah dari Dia, dan oleh Dia, dan kepada Dia...” melalui filosofi ini seluruh siswa di SMA Gamaliel dibawa kepada pengembangan pengetahuan, karakter serta iman yang terarah kepada Allah, sehingga diharapkan siswa dapat mengenal Allah dengan benar dan mengalami perjumpaan dengan Tuhan dalam kehidupannya. ${ }^{21}$

Adapun implementasi dari filosofi sekolah ini ialah adanya programprogram yang sasaran akhirnya membawa siswa menerima keselamatan di dalam Yesus dengan kesadaran yang timbul dari dirinya sendiri. Programprogram tersebut antara lain, retreat yang dilaksanakan setiap tahun khusus bagi siswa tahun terakhir pada setiap unit. Di SMA Gamaliel kegiatan ini wajib bagi siswa kelas XII dan dilaksanakan pada semester ke5. Dalam acara ini siswa dibawa kepada pengenalan kepada Allah dan dalam acara ini pula mereka ditantang untuk menerima Yesus sebagai Tuhan dan Juruselamat mereka secara pribadi. Selanjutnya sekolah melakukan follow up dengan membimbing mereka dalam hal kerohanian dengan mengarahkan mereka ke gereja. Dalam hal ini SMA Gamaliel bekerja sama dengan GKI Sulsel Jemaat Makassar. Retreat ini merupakan puncak dari seluruh rangkaian pembinaan kerohanian untuk mencapai tujuan utama, yaitu membawa siswa mengalami perjumpaan dengan Tuhan. Adapun program-program pendahulunya ialah: (1) Kegiatan doa bersama sebelum dan sesudah kegiatan belajar di kelas, dalam kegiatan ini disertai dengan renungan singkat firman Tuhan. (2) Ibadah mingguan sekolah, yang dilaksanakan rutin dan wajib bagi seluruh siswa. (3) Kegiatan Kebaktian Kebangunan Rohani. Kegiatan ini juga terprogram dengan baik. Dan puncak dari seluruh rangkaian pembinaan tersebut ialah dalam kegiatan

\footnotetext{
${ }^{20}$ Paul Djadi, Wawancara Oleh Penulis, Makassar, 18 Juli 2011.

${ }^{21}$ Indarto, Wawancara Oleh Penulis, Makassar, 19 Juli 2011.
} 
retreat. ${ }^{22}$ Menurut Bapak Paul Djadi, dalam kegiatan ini bila ada siswa yang tebuka hatinya untuk menerima keselamatan, maka guru PAK dan Guru BK akan membimbing mereka. ${ }^{23}$ Saat penulis melakukan wawancara paling tidak sudah ada dua orang siswa yang menerima Tuhan Yesus sebagai Tuhan dan Juruselamat mereka yang sebelumnya mereka berasal dari kepercayaan lain.

Pencapaian tujuan PAK bukan saja diusahakan dalam pelaksanaan mata pelajaran Agama Kristen saja. Dalam mata pelajaran umumpun tujuan ini merupakan hal yang harus dicapai. Itu sebabnya pelajaran umum diintegrasikan dengan nilai-nilai Alkitab, sehingga siswa tidak saja memiliki pengetahuan belaka, namun juga memiliki wawasan yang luas berdasarkan nilai-nilai Alkitab. Inilah yang tercermin dalam sistem pembelajaran yang disebut dengan The Learning Cyrcle, yang di dalamnya tercakup aspek knowledge, skill, character, dan Bible value. Diharapkan siswa akan memiliki nilai-nilai kehidupan Kristen, yaitu takut akan Tuhan, mencintai Tuhan dan sesama, rendah hati, percaya diri, menghormati sesama, peduli terhadap sesama, santun dalam berbicara, bersikap dan bertindak. $^{24}$

\section{Penerapan Metode Mengajar Yesus dalam Pelaksanaan PAK di SMA} Gamaliel Makassar

Tabel 7.

Prinsip Penerapan dan Kriteria Pemilihan Metode Mengajar

\begin{tabular}{|c|c|c|}
\hline $\begin{array}{l}\text { 13. Apakah anda merasa diaktifkan dalam kegiatan belajar- } \\
\text { mengajar di kelas? }\end{array}$ & $\mathrm{n}$ & $\%$ \\
\hline $\mathrm{Ya}$ & 64 & 64 \\
\hline Tidak & - & - \\
\hline Kadang-kadang & 36 & 36 \\
\hline $\mathrm{N}$ & 100 & 100 \\
\hline $\begin{array}{l}\text { 14. Apakah sekolah anda memiliki cukup fasilitas untuk } \\
\text { mendukung kegiatan belajar-mengajar? }\end{array}$ & $\mathrm{n}$ & $\%$ \\
\hline Ya & 83 & 83 \\
\hline Tidak & - & - \\
\hline Kadang-kadang & 17 & 17 \\
\hline $\begin{array}{llll}0 & 0 \\
\end{array}$ & 100 & 100 \\
\hline $\begin{array}{l}\text { 15. Dengan cara mengajar yang digunakan oleh guru anda, } \\
\text { apakah anda merasa memperoleh keterampilan yang nyata } \\
\text { dan bukan sekedar menguasai teori belaka? }\end{array}$ & $\mathrm{n}$ & $\%$ \\
\hline Ya & 79 & 79 \\
\hline Tidak & - & - \\
\hline Kadang-kadang & 21 & 21 \\
\hline 1 & 100 & 100 \\
\hline
\end{tabular}

\footnotetext{
${ }^{22}$ Paul Djadi, Wawancara Oleh Penulis, Makassar, 18 Juli 2011.

${ }^{23}$ Idem.

${ }^{24}$ Matheus Limbongan, Wawancara Oleh Penulis, Makassar, 18 Juli 2011.
} 
Dari hasil angket, penulis mendapatkan data sebagai berikut:

Pertama, berkaitan dengan keterlibatan siswa dalam kegiatan belajar mengajar, penulis mempertanyakan apakah metode yang guru terapkan mampu membangkitkan suasana positif yaitu keaktifan murid (pertanyaan nomor 13) pada tabel 7, didapatkan data sebagai berikut, sebanyak 64 orang responden siswa atau sebesar 64\% menjawab "ya" sedangkan 36 orang lainnya yaitu sebesar 36\% menjawab "kadang-kadang." Dari hasil ini dapat diketahui bahwa keterlibatan siswa menjadi pertimbangan dalam pemilihan metode belajar, namun pelaksanaannya masih belum maksimal, ini ditandai dengan masih ada sebagian responden yaitu 36\% menjawab opsi "kadang-kadang." Saat penulis menanyakan hal ini kepada guru mata pelajaran, guru tersebut menyatakan bahwa, "Dalam setiap mengajar sedapat mungkin siswa diaktifkan dalam kelas, karena sekarang bukan saatnya lagi diterapkan sistem mengajar satu arah. Siswa harus terlibat dalam kelas." ${ }^{25}$ Dalam hal ini guru harus berusaha meningkatkan keikutsertaan siswa secara aktif dalam proses belajar mengajar, sehingga murid tidak belajar secara pasif di dalam kelas. Guru harus kreatif dalam menggunakan metode mengajar, khususnya yang melibatkan siswa secara aktif alam proses belajar mengajar.

Kedua, pemilihan metode mengajar juga didasarkan pada ketersediaan fasilitas. Penulis mempertanyakan tentang hal ini melalui pertanyaan nomor 14 , sebanyak 83 orang responden siswa atau sebesar $83 \%$ menjawab "ya" sedangkan 17 orang lainnya yaitu sebesar 17\% menjawab "kadang-kadang." Dari hasil ini dapat diketahui bahwa fasilitas pendukung juga menjadi salah satu pertimbangan dalam menerapkan metode mengajar. Sebagian besar responden siswa yaitu sebesar 83\% sepakat bahwa sekolah mereka memiliki fasilitas yang memadai, khususnya bila dikaitkan dengan penerapan metode mengajar dalam pelaksanaan PAK di sekolah tersebut. Berdasarkan wawancara penulis Bapak Paul Djadi menyatakan bahwa, "Dalam penerapan metode mengajar, fasilitas yang dapat digunakan antara lain ruang kelas, serta alat bantu audio visual, yaitu seperangkat Laptop dan LCD Proyektor." ${ }^{26}$ Diharapkan pengelola sekolah senantiasa memperhatikan ketersediaan fasilitas di SMA Gamaliel Makassar, sehingga guru dapat maksimal menjalankan tugasnya sebagai pengajar, serta siswa dapat maksimal pula dalam belajar.

Ketiga, berkaitan dengan tercapainya keterampilan tertentu dari siswa sebagai peserta didik pertanyaan nomor 15 pada tabel 7 , jawaban yang

\footnotetext{
${ }^{25}$ Paul Djadi, Wawancara Oleh Penulis, Makassar, 31 Maret 2011.

${ }^{26}$ Paul Djadi, Wawancara Oleh Penulis, Makassar, 31 Maret 2011.
} 
diperoleh dari responden adalah sebanyak 79 responden siswa atau sebesar $79 \%$ menjawab "ya" sedangkan 21 orang responden lainnya yaitu sebesar $21 \%$ menjawab "kadang-kadang." Hal ini menunjukkan bahwa pencapaian keterampilan tertentu dari para siswa juga menjadi pertimbangan bagi guru untuk menerapkan metode mengajar, sehingga siswa tidak hanya menguasai teori belaka. Dan pada kenyataannya siswa memiliki keterampilan-keterampilan, khususnya dalam bidang rohani. Berdasarkan pengamatan penulis di lapangan, penulis mendapati siswa mampu memimpin ibadah singkat sebelum pelajaran dimulai. Hal ini dipertegas oleh Bapak Paul Djadi dalam wawancara dengan penulis, "Siswa di sekolah ini dilatih untuk dapat memimpin doa, membawakan renungan serta memimpin ibadah sebelum masuk kelas." ${ }^{27}$ Diharapkan guru dapat terus meningkatkan hal ini mengingat dari data angket siswa masih didapati jawaban "kadang-kadang" sebesar $21 \%$ saat ditanyakan mengenai hal ini. Ini berarti sebagian kecil responden belum merasa memiliki keterampilanketerampilan tertentu setelah mereka menerima pelajaran di sekolah, khususnya pada pelajaran Agama Kristen.

Masih berkaitan dengan prinsip penerapan dan kriteria pemilihan metode mengajar, penulis melakukan wawancara dengan Bapak Paul Djadi selaku guru PAK di SMA Gamaliel untuk mengetahui apakah guru sudah menerapkan metode mengajar sesuai prinsip-prinsip yang ada dan apakah selain tiga kriteria yang penulis pertanyakan kepada siswa ada kriteriakriteria lainnya sebagai pertimbangan guru dalam pemilihan metode mengajar. Dari wawancara yang dilakukan penulis mendapatkan data sebagai berikut:

Pertama, berkaitan dengan prinsip penerapan metode mengajar penulis mempertanyakan, "Menurut anda, apakah metode yang anda gunakan dalam mengajar dapat membantu mencapai tujuan pembelajaran?" Penulis mendapatkan jawaban bahwa, "Metode-metode mengajar yang saya gunakan sangat membantu untuk mencapai tujuan pembelajaran." ${ }^{28} \mathrm{Hal}$ ini menunjukkan bahwa guru sebagai pelaksana PAK menyadari bahwa metode merupakan suatu sarana dalam pencapaian tujuan, khususnya tujuan PAK di sekolah.

Kedua, selanjutnya masih dalam kaitannya dengan prinsip penerapan metode mengajar penulis mempertanyakan, "Apakah anda menggunakan metode yang sama secara terus menerus?" Penulis mendapat jawaban "Tidak, biasanya saya menggabungkan lebih dari satu macam metode dalam setiap mengajar. Misalnya metode ceramah diintegrasikan dengan diskusi." ${ }^{29}$ Lebih lanjut penulis mendapat penjelasan bahwa, masing-masing metode mempunyai kekuatan dan kelemahan, dan metode mengajar tidak

\footnotetext{
${ }^{27}$ Paul Djadi, Wawancara Oleh Penulis, Makassar, 31 Maret 2011.

${ }^{28}$ Idem.

${ }^{29}$ Paul Djadi, Wawancara Oleh Penulis, Makassar, 31 Maret 2011.
} 
selalu dapat diterapkan pada semua situasi. Hal ini menunjukkan sebuah kesadaran bahwa masing-masing metode mempunyai kekuatan dan kelemahan dan juga kesadaran bahwa bisa saja berbagai metode diintegrasikan menjadi satu demi efektivitas kegiatan pembelajaran itu sendiri.

Ketiga, berkaitan dengan kriteria penerapan metode mengajar khususnya dalam hal kemampuan guru dalam menggunakan metode mengajar, penulis mempertanyakan, "Apakah anda menguasai dengan baik setiap metode yang anda gunakan? Dalam hal ini penulis mendapat jawaban bahwa, "Setiap guru harus mampu menerapkan metode mengajar dengan tepat, termasuk di dalamnya kemampuan menggunakannya. Untuk itu guru dibekali dengan pelatihan-pelatihan yang dilaksanakan setiap tahun pada masa liburan sekolah. Pelatihan ini bertujuan untuk meningkatkan profesionalitas guru." 30 Hal ini menunjukkan bahwa faktor penguasaan metode adalah faktor penting yang disadari oleh guru, sehingga guru merasa perlu mengikuti setiap pelatihan yang diselenggarakan oleh pihak sekolah.

Keempat, berkaitan dengan kriteria penerapan metode mengajar khususnya dalam hal kebutuhan peserta didik, penulis mempertanyakan, "Apakah pemilihan metode mengajar disesuaikan dengan kebutuhan siswa?" Dalam kaitannya dengan hal ini penulis mendapatkan jawaban bahwa kebutuhan siswa menjadi salah satu pertimbangan dalam menerapkan metode mengajar yang tepat. Mengenai kebutuhan-kebutuhan siswa penulis tidak mendapat penjelasan lebih detail. Namun Bapak Paul Djadi memberikan penjelasan bahwa dalam mengetahui kebutuhankebutuhan siswa perlu ada pendekatan yang baik dengan siswa, sehingga guru mampu memahami apa yang siswa butuhkan dalam kaitannya dengan kegiatan belajar mengajar di kelas. ${ }^{31}$

Kelima, berkaitan dengan kriteria penerapan metode mengajar khususnya mengenai pertimbangan jumlah peserta didik, penulis mempertanyakan, "Apakah jumlah siswa menjadi pertimbangan dalam penerapan metode mengajar ketika anda mengajar? Berapa jumlah rata-rata siswa per kelas di SMA Gamaliel?" penulis mendapatkan jawaban sebagai berikut, "Tentu, mengingat salah satu efektivitas kegiatan belajar mengajar di kelas tergantung juga dari jumlah murid per kelas. Sekolah ini mempunyai jumlah siswa yang cukup merata pada setiap kelas, yaitu berkisar antara 32 orang sampai 34 orang per kelas." ${ }^{32}$

Keenam, penulis mempertanyakan juga mengenai "Apakah tujuan pelajaran menjadi pertimbangan anda dalam menentukan metode mengajar yang akan anda gunakan?" penulis mendapat jawaban, "Tentu saja, karena

\footnotetext{
${ }^{30}$ Idem.

${ }^{31}$ Paul Djadi, Wawancara Oleh Penulis, Makassar, 31 Maret 2011.

${ }^{32}$ Idem.
} 
bagaimanapun metode mengajar merupakan sarana mencapai tujuan.. ${ }^{33} \mathrm{Hal}$ ini dapat diinterpretasikan bahwa guru mempertimbangkan tujuan pelajaran dalam menentukan metode mengajar yang akan diterapkan dengan harapan bahwa kegiatan belajar mengajar di kelas dapat berlangsung efektif.

Ketujuh, dalam kaitannya pemilihan metode mengajar berdasarkan kesesuaian dengan bahan pelajaran, penulis mempertanyakan kepada guru, "Apakah bahan pelajaran menjadi pertimbangan anda dalam menentukan metode mengajar yang akan anda gunakan?" penulis mendapatkan jawaban, "Ya, saya sebagai guru harus dapat melihat sejauh mana bahan pelajaran/materi digunakan dalam metode mengajar saya, misalnya materi apa yang cocok untuk didiskusikan di kelas dan sebagainya"34 Dari hasil wawancara ini menunjukkan bahwa guru mempertimbangkan bahan pelajaran dalam memilih metode mengajar yang tepat.

Kedelapan, kriteria berikutnya dalam penerapan metode mengajar ialah ketersediaan waktu. Berkaitan dengan hal ini penulis mempertanyakan kepada responden guru, "Apakah ketersediaan waktu menjadi pertimbangan anda dalam menentukan metode mengajar yang akan anda gunakan?" Penulis mendapat jawaban, "Ya, dengan melihat alokasi waktu yang tersedia bagi masing-masing pembahasan guru dapat memikirkan metode apa yang akan digunakan, misalnya bila ada materi yang penting namun waktu yang tersedia hanya sedikit, maka metode ceramah yang diterapkan. Lain halnya bila waktu tersedia cukup banyak, maka bisa juga dilakukan diskusi." ${ }^{35}$

\section{Kesimpulan Analisis Data}

Beberapa hal yang dapat disimpulkan dari hasil analisis data tersebut di atas dapat penulis kemukakan bahwa dalam pelaksanaan PAK di SMA Gamaliel Makassar yang tertuang dalam penyelengaraan mata pelajaran Agama Kristen digunakan beberapa metode mengajar yang intensitas pengunaannya berbeda-beda. Dari hasil penelitian dapat diketahui bahwa:

Pertama, guru menggunakan pertanyaan-pertanyaan, antara lain pertanyaan yang memotivasi siswa, juga pertanyaan evaluatif yang membuat siswa memikirkan kembali pemahaman mereka sehingga mereka memperoleh pemahaman yang lebih baik. Selain itu ada pula bentuk pertanyaan analitis yang membawa siswa lebih dalam lagi memikirkan halhal yang telah dipelajari. Lewat semua bentuk dalam metode pertanyaan siswa diharapkan akan dapat memahami secara mendalam semua yang telah dipelajari dalam kelas. Adapun intensitas penggunaanya dapat disimpulkan bahwa masing-masing bentuk tidak selalu digunakan dalam

\footnotetext{
${ }^{33}$ Idem.

${ }^{34}$ Paul Djadi, Wawancara Oleh Penulis, Makassar, 31 Maret 2011.

${ }^{35}$ Idem.
} 
kegiatan pembelajaran, namun disesuaikan dengan kebutuhan dan situasi yang ada. Untuk menentukan bentuk pertanyaan yang tepat, guru dituntut untuk dapat melihat situasi dan kebutuhan pada setiap kegiatan belajar mengajar dalam kelas.

Kedua, dari hasil penelitian dapat disimpulkan bahwa guru pada prinsipnya menggunakan metode cerita dalam tugasnya sebagai pengajar, namun jarang menggunakan cerita sebagai pendahuluan. Guru menyisipkan cerita-cerita yang sesuai dengan bahan pelajaran untuk menolong siswa memahami materi yang sedang dipelajari.

Ketiga, dalam menyampaikan bahan pelajaran, metode ceramah digunakan yang kadangkala diintegrasikan dengan metode-metode yang lain, seperti metode pertanyaan, cerita, menggunakan alat peraga, dalam hal ini penggunaan fasilitas LCD proyektor dan juga metode diskusi.

Keempat, dari hasil penelitian didapati guru jarang menggunakan alat peraga, karena hampir seluruh responden siswa yang menjawab opsi jawaban "kadang-kadang." Berdasarkan wawancara dengan penulis, alat peraga yang biasa digunakan adalah proyektor LCD.

Kelima, dari hasil penelitian dijumpai bahwa guru dalam menyampaikan bahan pelajaran dapat dikatakan jarang menggunakan metode diskusi. Metode ini diintegrasikan dengan metode ceramah di kelas.

Keenam, dari hasil angket yang disebarkan kepada sejumlah responden dan juga wawancara kepada narasumber terkait, didapati bahwa dalam pelaksanaan PAK di SMA Gamaliel Makassar guru mendorong siswa untuk bertumbuh dalam iman kepada Tuhan, serta mengalami perjumpaan dengan Tuhan. Untuk mencapai hal ini siswa didorong untuk mengenal Allah melalui kegiatan-kegiatan rohani seperti doa bersama, ibadah, KKR dan juga retreat. Di samping itu dalam setiap kegiatan pembelajaran, siswa mempelajari mata pelajaran yang diintegrasikan dengan nilai-nilai Alkitabiah. Di SMA Gamaliel siswa bukan saja dituntut untuk memiliki pengetahuan yang bertambah dalam hal kerohanian, namun juga bertambah terampil dalam hal-hal rohani, seperti berdoa, bahkan mereka mampu memimpin ibadah di kelas dan menyampaikan renungan singkat dari Firman Tuhan dan juga memiliki budi pekerti yang baik. Selain itu siswa juga disadarkan akan perannya dalam masyarakat.

Ketujuh, dalam hal penerapan metode mengajar, dapat dikatakan telah memenuhi kriteria-kriteria yang ada, seperti: kemampuan dan keterampilan guru dalam menggunakan metode yang diterapkannya, kebutuhan peserta didik, jumlah siswa atau besarnya kelompok, tujuan pelajaran, keterlibatan peserta didik, kesesuaian dengan bahan pelajaran, ketersediaan fasilitas pendukung, ketersediaan waktu, serta keterampilan tertentu yang dihasilkan. Dari hasil penelitian dapat disimpulkan metodemetode yang dapat membantu guru dalam pencapaian tujuan PAK di SMA Gamaliel Makassar antara lain metode pertanyaan, cerita 
(perumpamaan/ilustrasi) dan ceramah, hal ini dapat dilihat dari intensitas penggunaan oleh guru dan hasil yang dicapai.

\section{PENUTUP}

\section{Kesimpulan}

Pada akhir dari penulisan karya ilmiah ini, penulis memberikan kesimpulan sebagai berikut:

Pertama, dalam pelayanan-Nya sebagai pengajar Yesus menggunakan beberapa metode. Metode, metode yang Yesus gunakan antara lain, metode pertanyaan, metode cerita (perumpamaan/ilustrasi), metode ceramah (khotbah), menggunakan benda atau objek sebagai alat peraga dan juga menggunakan metode diskusi. Dapat dikatakan bahwa Yesus adalah guru yang kreatif, karena dalam setiap pengajaran-Nya Yesus menggunakan metode-metode yang bervariasi, bergantung kepada tujuan, bahan, situasi pendengar, serta lingkungan-Nya.

Kedua, Pendidikan Agama Kristen (PAK) merupakan bagian dari proses pendidikan secara umum. Pelaksanaan PAK khususnya di sekolah termasuk pendidikan yang khusus karena menyangkut dimensi religius manusia. Adapun tujuannya ialah membawa kehidupan manusia mengenal Allah dan mampu hidup memuliakan Allah. Secara khusus dalam pelaksanaannya di sekolah, paling tidak ada tiga aspek dari kehidupan siswa sebagai peserta didik yang menjadi titik berat tujuan pelaksanaan PAK, yaitu: (1) Aspek spiritual, dalam aspek ini peserta didik dibawa dalam pertumbuhan iman kepada Allah. (2) Aspek personal, dalam aspek ini siswa sebagai peserta didik pada akhirnya memiliki pengetahuan keagamaan yang terus bertambah, semakin terampil dalam hal-hal rohani, serta memiliki budi pekerti yang baik. (3) Aspek sosial, dalam aspek ini peserta didik dibawa dalam sebuah kesadaran bahwa hidup mereka harus berdampak bagi masyarakat di mana mereka tinggal. Sehingga selepas dari bangku sekolah, ketika mereka terjun dalam masyarakat mereka akan berperan dalam pembangunan masyarakat bahkan bangsa. Untuk mencapai hal ini diperlukan guru yang memenuhi kualifikasi kerohanian yang memadai, yaitu guru sebagai pelaksana PAK haruslah orang yang telah menyerahkan kehidupannya kepada Yesus, mengalami pertumbuhan iman, memiliki beban untuk membawa peserta didik menerima keselamatan di dalam Yesus dan memiliki ketergantungan kepada kuasa dan urapan Roh Kudus.

Ketiga, berkaitan dengan usaha pencapaian tujuan dalam pelaksanaan PAK di sekolah, yaitu perjumpaan peserta didik dengan Allah, metode mengajar merupakan salah satu faktor penting. Namun demikian perlu adanya keseimbangan antara strategi yang dilaksanakan di dalam kelas, dalam hal ini penerapan metode mengajar dan juga strategi yang dikerjakan guru dan sekolah di luar kelas. Dalam hubungannya dengan pelaksanaan 
PAK di SMA Gamaliel, tujuan ini sudah diupayakan melalui kegiatankegiatan di dalam kelas, yaitu melalui pelajaran Agama Kristen, dan juga pelajaran umum yang diintegerasikan dengan nilai-nilai Alkitabiah. Adapun kegiatan pendukung lainnya yang dikerjakan di luar kelas antara lain, ibadah bersama, program KKR serta retreat yang memungkinkan siswa mengambil keputusan untuk menerima Yesus sebagai Tuhan dan Juruselamat mereka.

Keempat, dalam hal penerapan metode mengajar Yesus di SMA Kristen Gamaliel dapat dikatakan bahwa guru yang bertanggung jawab dalam pelaksanaan PAK di sekolah ini menggunakan beberapa metode mengajar yang Yesus gunakan selama pelayanan-Nya di bumi. Dari sekian metode yang ada hanya metode menggunakan alat peraga dan diskusi saja yang dapat dikatakan jarang digunakan. Dalam penerapannya di lapangan, beberapa kriteria menjadi bahan pertimbangan guru, antara lain kemampuan dan keterampilan guru dalam menggunakan metode yang diterapkannya, kebutuhan peserta didik, jumlah siswa atau besarnya kelompok, tujuan pelajaran, keterlibatan peserta didik, kesesuaian dengan bahan pelajaran, ketersediaan fasilitas pendukung, ketersediaan waktu, serta keterampilan tertentu yang dihasilkan.

Kelima, metode mengajar Yesus masih relevan bila digunakan pada masa kini. Hal ini dapat dilihat dari hasil penelitian yang penulis lakukan di SMA Gamaliel Makassar, penulis mendapatkan data bahwa guru PAK di SMA Gamaliel Makassar menggunakan metode-metode mengajar yang Yesus gunakan.

\section{Saran} lain:

Melalui penulisan ini, penulis memberikan beberapa saran, antara

Pertama, hendaknya guru belajar dari Yesus yang dapat dengan kreatif menggunakan metode-metode yang tepat dalam mengajar.

Kedua, hendaknya guru dapat menganalisa secara tepat keadaan dan situasi serta kriteria-kriteria tertentu dalam penerapan metode mengajar, sehingga guru yang bersangkutan dapat menentukan metode yang tepat dalam mengajar.

Ketiga, hendaknya guru dapat membawa peserta didik mencapai tujuan yang diharapkan dalam pelaksanaan PAK di sekolah melalui penggunaan metode mengajar yang tepat. Selain itu guru juga harus memikirkan cara untuk membawa peserta didik mengalami perjumpaan dengan Tuhan, bukan saja melalui kegiatan pembelajaran dalam kelas, namun juga melalui kegiatan di luar kelas. Adapun jenisnya dapat berupa kegiatan retreat dan ditindak lanjuti dengan pembinaan dalam kelompok kecil, sehingga peserta didik dapat seluruhnya menerima keselamatan di dalam Yesus. 
Keempat, bagi badan penyelenggara pendidikan Gamaliel, dalam hal ini Komisi Pendidikan GKI Sulsel Jemaat Makassar, perlu terus meningkatkan efektivitas program-program yang telah ada dengan cara melakukan evaluasi berkala terhadap program-program tersebut, supaya tujuan yang tertuang dalam visi dan misi sekolah dapat tercapai. Selain itu perlu adanya penemuan-penemuan baru berkaitan dengan strategi dalam pencapaian tujuan PAK di SMA Gamaliel, misalnya pembinaan dalam kelompok kecil sehingga semakin hari semakin banyak siswa yang mengalami perjumpaan dengan Tuhan dalam kehidupannya. Dalam kaitannya dengan penerapan metode mengajar hendaknya Komisi Pendidikan juga perlu mendorong guru sebagai pelaksana PAK untuk meningkatkan kemampuannya dalam mengajar termasuk dalam menggunakan metode mengajar dengan cara mengadakan pelatihan-pelatihan, sehingga guru memiliki kreativitas dan keterampilan dalam menggunakan metode-metode mengajar. 


\section{KEPUSTAKAAN}

“Profil Sekolah Gamaliel."Gamalielschool.org; diakses tanggal 15 April 201; tersedia

http://gamalielschool.org/index.php?option=com_content\&eview=artic le\&id=7:profile-sekolah-gamaliel\&ecatid=1:profile-sekolah\&Itemid=9.

Daniel Nuhamara, Pembimbing PAK (Bandung: Jurnal Info Media, 2007), 137.

Homrighausen dan I.H. Enklaar, Pendidikan Agama Kristen (Jakarta: BPK Gunung Mulia, 2004), 74.

Husaini Usman dan Purnomo Setiady Akbar, Metodologi Penelitian Sosial (Jakarta: Bumi Aksara, 1996), 59.

Indarto, Wawancara Oleh Penulis, Makassar, 19 Juli 2011.

Kamus Besar Bahasa Indonesia, s.v. "Metode."

Kamus Besar Bahasa Indonesia, s.v. "Pendidikan."

Matheus Limbongan, Wawancara Oleh Penulis, Makassar, 18 Juli 2011.

Moh. Nazir, Metode Penelitian (Jakarta: Ghalia Indonesia, 1988), 325.

Mohamad Ali, Penelitian Kependidikan (Bandung: Angkasa, 1981), 184.

Paul Djadi, Wawancara Oleh Penulis, Makassar, 18 Juli 2011.

Paul Enns, The Moody Handbook of Theology Jilid 1 (Malang: Literatur SAAT, 2004), 91.

Paulus Lilik Kristianto, Prinsip dan Praktek Pendidikan Agama Kristen (Yogyakarta: Penerbit ANDI, 2006), 83.

Sumanto, Metodologi Penelitian Sosial dan Pendidikan (Yogyakarta: Penerbit Andi Offset, 1990), 23.

Sutrisno Hadi, Metodologi Research Jilid 2 (Yogyakarta: Penerbit Andi Offset, 1990), 158.

Winarno Surachmad, Dasar dan Tehnik Research Pengantar Metodologi Ilmiah (Bandung: Tarsito, 1978), 134. 